\title{
Re-assessment of ammonoid specimens from the Early Carboniferous Protocanites Beds of the Badenweiler-Lenzkirch Zone (Schwarzwald, Central Variscan Belt): age constraints for a lithostratigraphic key bed
}

\author{
Dieter Korn $^{1}$ D $\cdot$ Michael Montenari
}

Received: 8 November 2020 / Accepted: 31 July 2021

(c) The Author(s) 2021

\begin{abstract}
The Protocanites Beds of the Black Forest Massif (Germany) form an important lithostratigraphic key bed, as the index fossils contained in this formation enable correlation within large areas of the internal zone of the central Variscan Belt of Europe. Furthermore, the formation provides significant information on the geodynamic evolution of the Moldanubian Zone. The stratigraphic age of the formation has been a subject of controversy in the past; a Devonian to Viséan age has been proposed. To determine the age of the Protocanites Beds, two ammonoid specimens from the Protocanites Beds of Schönau are re-described here. They belong to Becanites abnobensis and Pericylcus princeps and fix the stratigraphic position of the Protocanites Beds to the early Late Tournaisian.
\end{abstract}

Keywords Black Forest Massif · Tournaisian · Ammonoidea $\cdot$ Biostratigraphy $\cdot$ Correlation

\section{Introduction}

Deciphering the geological framework within the internal zone of the central European Variscan Belt is very difficult (for the latest review, see Franke et al. 2000), as reliable biostratigraphic age determinations are rare and lithostratigraphic correlation is often questionable due to the lack of unambiguous marker beds and intensive tectonic dislocations. One of the scarce marker horizons within the Moldanubian Black Forest Massif is the Protocanites Beds with their type locality at the city of Schönau im Wiesental; this formation was proven to serve as a lithostratigraphic key. Geochemical analysis together with sedimentological and petrographic investigations of this formation (Güldenpfennig

Handling Editor: Sven Hartenfels.

Dieter Korn

dieter.korn@mfn-berlin.de

Michael Montenari

m.montenari@keele.ac.uk

1 Museum für Naturkunde Berlin, Leibniz-Institut für Evolutions- und Biodiversitätsforschung, Invalidenstraße 43, 10115 Berlin, Germany

2 Department of Earth Sciences and Geography, Keele University, Newcastle, Staffs., UK
1997, 1998) led to a plate tectonic model (Loeschke et al. 1998) for the Moldanubian Black Forest Massif, in which the Badenweiler-Lenzkirch Zone was interpreted as a major Variscan suture Zone. However, the age of the Protocanites Beds and consequently the onset of subduction was controversial when taking the plate tectonic model proposed by Loeschke et al. (1998) into account.

Usually, the Protocanites Beds were interpreted as Early Carboniferous in age (Burgath and Maass 1973; Güldenpfennig 1997 with additional references therein; see Sittig 1961). However, Hann and Sawatzki (1998) suggested a general Devonian age of the formation on the basis of palynological investigations of this important marker horizon. The considerable contrast between the classical stratigraphic age assignment and new age determinations makes it necessary to reinvestigate and re-evaluate the name-giving ammonoid from the type locality of the Protocanites Beds.

\section{Geological setting}

The Black Forest (Schwarzwald) is part of the Variscan Belt of Europe, which formed in Devonian-Carboniferous times by the collision of Gondwana, Laurussia, and microplates in between (Franke 2000; Franke et al. 1995; Matte 1991). While the northernmost part (the Baden-Baden Zone) 
belongs to the Saxothuringian Zone, the central and southern areas are assigned to the Moldanubian Zone (sensu Kossmat 1927). The Black Forest Massif itself can be subdivided into four fault-bound tectonic units:

(1) The Baden-Baden Zone (BBZ) hosts accreted crustal fragments of distinct tectonometamorphic evolution (Wickert et al. 1990) and greenschist facies metasediments (Sittig 1965) of Cambro-Ordovician age (Montenari and Servais 2000; Montenari et al. 2000).

(2) The Central Schwarzwald Gneiss Complex (CSGC) contains metapsammitic gneisses and migmatites, which have undergone different metamorphic conditions (for a overview, see Kalt et al. 2000). During the Variscan convergence, the CSGC was tectonically juxtaposed against the Baden-Baden Zone in the north and also thrusted over the Badenweiler-Lenzkirch Zone (BLZ) to the south.

(3) The Badenweiler-Lenzkirch Zone (Fig. 1c) is an approximately E-W-trending thrust and fault zone of $40 \mathrm{~km}$ length and 3-4 km width (Maass et al. 1991; Sittig 1981; von Bubnoff 1912, 1921). It comprises metasedimentary units (e.g., Altherr and Maass 1977; Werling and Altherr 1987; Wimmenauer et al. 1981; Ziegler and Wimmenauer 2001), for which a Wenlock to Pridoli age is proven (Montenari et al. 2000), and non-metamorphic volcanosedimentary successions of Late Devonian (Kneidl et al. 1982; Weyer 1962) to Early Carboniferous age (Sittig 1961; Vöhringer 1960; Spiegelhalter 1910).

(4) To the south, the Badenweiler-Lenzkirch Zone is bordered against the Southern Schwarzwald Gneiss Complex (SSGC) by an E-W-trending and steeply $\mathrm{N}$-dipping fault. The SSGC consists of metaluminous to slightly peraluminous biotite granites and two-mica granites of peraluminous composition (Kalt et al. 2000). Besides the granites, it hosts also a gneissleptynite complex and the Wehra-Wiesetal Diatexite (Wimmenauer 1984).

The Protocanites Beds (also termed Protocanites Greywackes) are part of the non-metamorphic volcanosedimentary sequences of the Badenweiler-Lenzkirch Zone. They have a thickness of more than $500 \mathrm{~m}$ (Kneidl et al. 1982) and occur within the entire, marine parts of the zone where they can serve as an important lithostratigraphic marker formation. The formation can be correlated within the Badenweiler-Lenzkirch Zone as well as with the timeequivalent deposits of the Moldanubian Southern Vosges Basin (France) and the north-eastern part of the French Massif Central (Eisele et al. 2000; Leloix et al. 1999; e.g., Maass 1988; Maass et al. 1991). Wilser (1933) coined the term for relatively immature, medium grain-sized greywackes, which yielded the index ammonoid (first determined Prolecanites cf. Lyoni by Spiegelhalter 1910) at the quarry near the forestry office of Schönau im Wiesental. While earlier workers (Metz and Rein 1958; Schäfer 1957; e.g., von Bubnoff 1919) compared and correlated the Protocanites Beds with the metamorphosed succession of the Gschwend-Sengalenkoopf Series (sensu Altherr and Maass 1977), Sittig (1963, 1969) was the first who recognized their significance as an independent lithostratigraphic element.

Detailed petrographic and geochemical investigations of the Protocanites Beds and the tectonically emplaced Late Devonian shales (Kneidl et al. 1982; Weyer 1962) were carried out by Güldenpfennig and Loeschke (1991) and Güldenpfennig $(1997,1998)$ concluding that the Protocanites Beds are deposits representing only a limited time interval. The restricted period of their occurrence together with the remarkable lateral distribution emphasize their importance as a lithostratigraphic key horizon.

\section{The stratigraphic age of the Protocanites Beds}

There are a variety of age determinations for the Protocanites Beds of the Badenweiler-Lenzkirch Zone. Starting with Spiegelhalter (1910), the formation was attributed to the Early Carboniferous. Vöhringer (1960) suggested, in his new description of the subspecies "Protocanites supradevonicus abnobensis", an age of the younger part of the Gattendorfia Stufe (=Early Tournaisian) or a little younger. Thanks to the discovery of a specimen of Pericylcus princeps (de Koninck, 1844) in the Protocanites Beds at Schönau in 1961, a Tournaisian age of the greywackes could be confirmed (Sittig 1967). Later authors then used this stratigraphic date (e.g., Güldenpfennig 1997, 1998; Maass 1988, 2005, 2006; Güldenpfennig and Loeschke 1991; Maass et al. 1991; Huth and Zedler 2019; Kneidl et al. 1982).

Hann and Sawatzki (1998) carried out palynological investigations on the Protocanites Beds and questioned the previous age determination of the Protocanites Beds. They recovered palynomorphs (acritarchs and chitinozoans) of Ordovician, Silurian, and also Devonian age from five samples, but only one of them (Präg, Sägentobel) yielded Devonian taxa. They concluded an undifferentiated Devonian time for the deposition of the Protocanites Beds, whilst the Ordovician and Silurian fossils were regarded as recycled (Hann and Sawatzki 1998, p. 186, 188). In subsequent papers, Hann et al. (2003), Vaida et al. (2004) and Hegner et al. (2005) regarded the Protocanites greywackes as Late Devonian to Early Carboniferous in age, while Brockamp et al. (2015), without providing evidence, suggested an early Viséan age. Already earlier, Schaltegger (2000) suggested a Tournaisian 

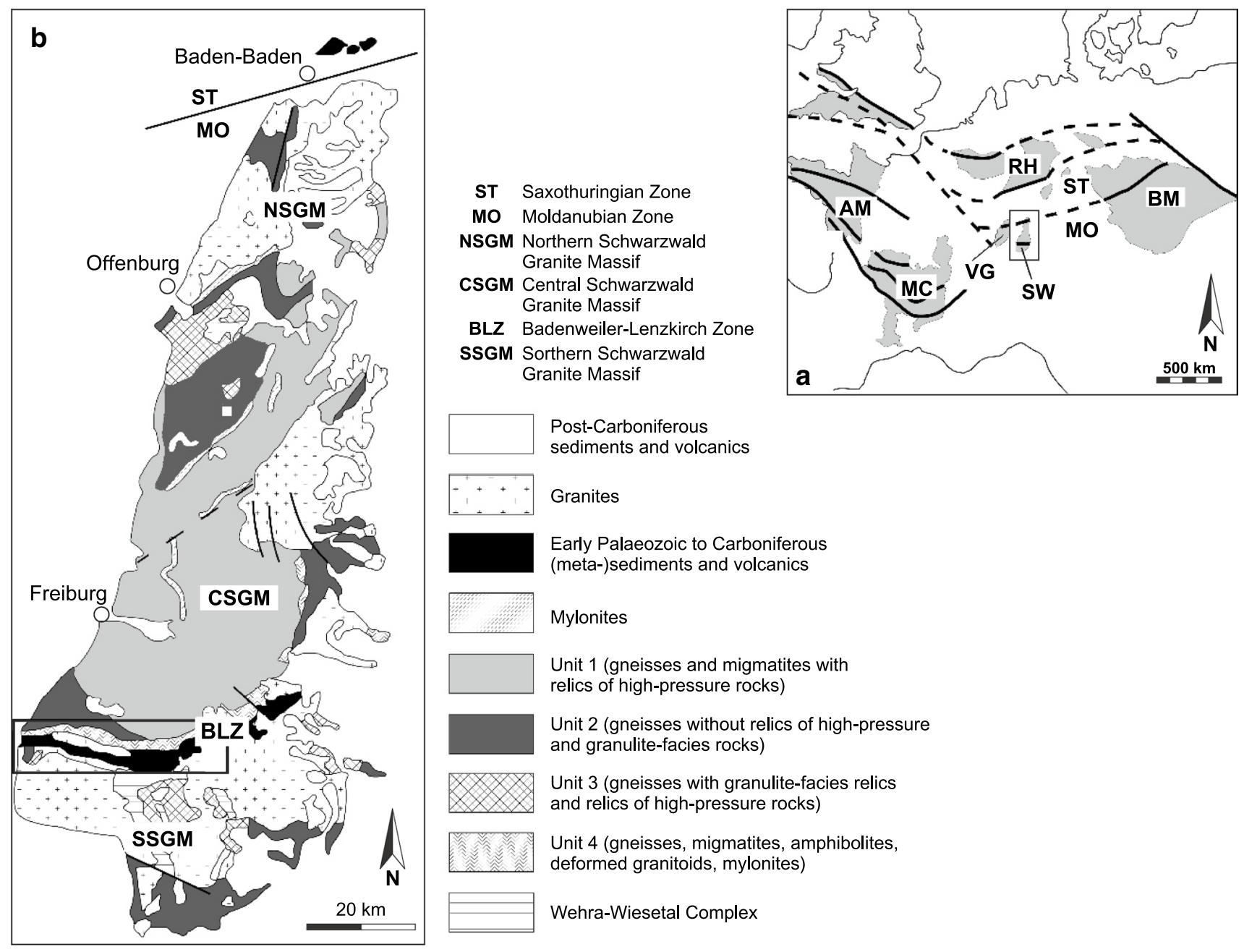
Unit 2 (gneisses without relics of high-pressure and granulite-facies rocks)

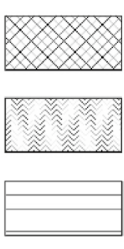

Unit 3 (gneisses with granulite-facies relics and relics of high-pressure rocks)

Unit 4 (gneisses, migmatites, amphibolites, deformed granitoids, mylonites)

Wehra-Wiesetal Complex

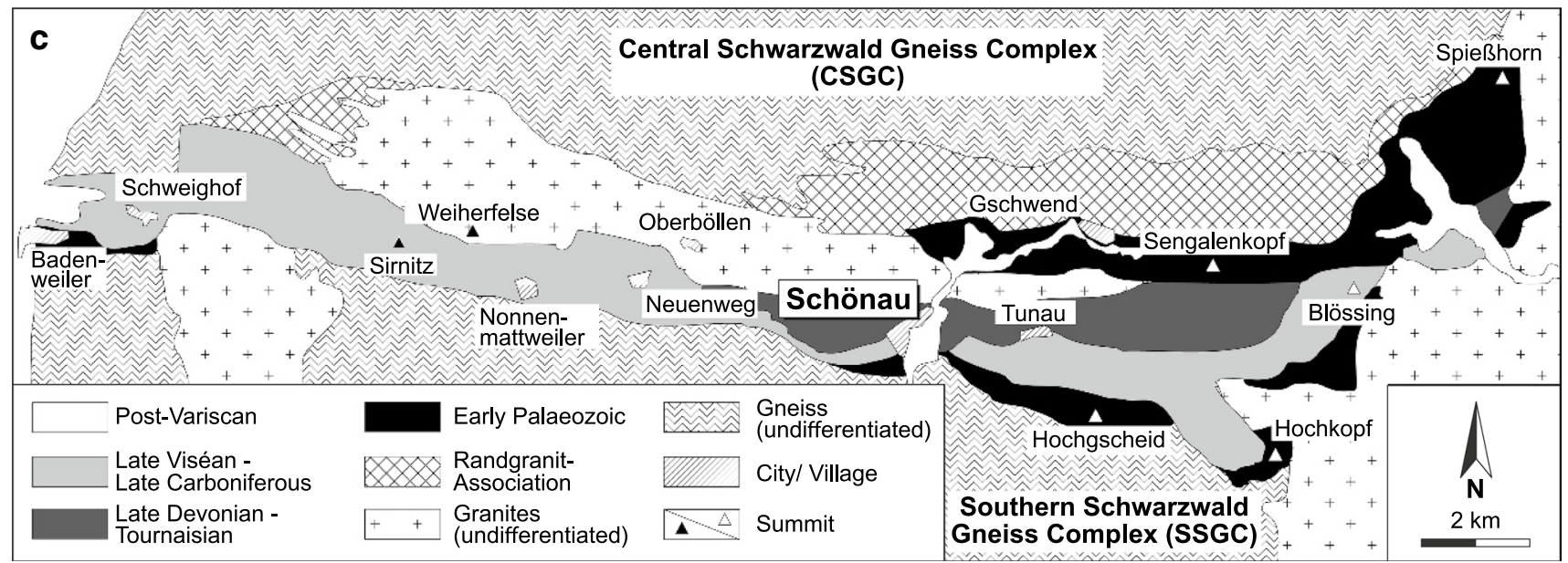

Fig. 1 Geological map of the Badenweiler-Lenzkirch Zone, the Black Forest and its position within the mid-European Variscan Belt. a Relationship between the Schwarzwald and the mid-European Variscan Belt (modified after Franke 1989). AM Armorican Massif, $M C$ Massif Central, $V G$ Vosges, $S W$ Schwarzwald, $B M$ Bohemian Massif, RH Rhenohercynian Zone, ST Saxothuringian Zone, MO Moldanubian Zone. b Geological outline and main characteristics of the Schwarzwald (modified after Kalt et al. 2000). BBZ Baden-Baden Zone, NSGM Northern Schwarzwald Granite Massif, CSGC Central Schwarzwald Gneiss Massif, BLZ Badenweiler-Lenzkirch Zone, SSGC Southern Schwarzwald Gneiss Massif. c Simplified geological framework of the Badenweiler-Lenzkirch Zone with particular emphasis on the city of Schönau with the type locality of the discussed Protocanites Beds (modified after Burgath and Maass 1973) 
to Viséan age of the Protocanites Greywacke that overlies Frasnian green and yellow shales.

The co-occurrence of the ammonoid genera Becanites and Pericyclus allows a precise age determination. While Becanites has a longer stratigraphic range from the Early to the Late Tournaisian, Pericyclus provides a constraint age of early Late Tournaisian. Becanites is known from the Gattendorfia Limestone of Dzikowiec in Lower Silesia (unpublished material), Middle Tournaisian strata such as the Bordalete Formation of South Portugal (Korn 1997) and the Oued Znaïgui Formation of the Anti-Atlas of Morocco (Korn et al. 2007) as well as early Late Tournaisian strata such as the Upper Kahla Formation of Gourara of western Algeria (Korn et al. 2010b) and the Teguentour Formation of the Mouydir of southern Algeria (Korn et al. 2010a).

The genus Pericyclus appears to be restricted to a limited early Late Tournaisian time interval. It was originally described from rare finds in the Calcaire de Calonne of Belgium (Delépine 1940; de Koninck 1844) and the Oued Znaïgui Formation of the Anti-Atlas of Morocco (Korn et al. 2003, 2007; Korn and Klug 2015). The most diverse assemblages with up to twenty species including several species of Pericyclus are in the Upper Kahla Formation of Gourara of western Algeria (Korn et al. 2010b) and the Teguentour Formation of the Mouydir of southern Algeria (Korn et al. 2010a). In summary, the co-occurrence of the two ammonoids allows only a stratigraphic attribution in the early Late Tournaisian, i.e., with a geochronological age of approximately $350 \mathrm{Ma}$ according to the geological time scale (Davydov et al. 2012).
The second precise stratigraphic date in the lower portion of the greywacke, which is based on conodonts (Kneidl et al. 1982; Weyer 1962), provides an Early to Middle Famennian age. This means a geochronological age of approximately $365 \mathrm{Ma}$ according to the geological time scale (Becker et al. 2012), i.e., much younger than the youngest zircons from the greywackes of the Badenweiler-Lenzkirch Zone, dated 384-371 Ma (Gruler et al. 1999).

\section{Palaeontological descriptions}

\section{Genus Pericyclus von Mojsisovics, 1882}

Pericyclus princeps (de Koninck, 1844)

Figure 2c

1844 Ammonites princeps de Koninck: 579, pl. 51, figs. 2, 3. 1880 Goniatites princeps de Koninck-de Koninck: 116, pl. 49, figs. 1, 2 .

1940 Pericyclus princeps (de Koninck)—Delépine: 38, pl. 1, figs. 12-15.

Description. The single poorly preserved specimen GZG 190-1 (Geowissenschaftliches Museum, Georg-August-Universität Göttingen) with a conch diameter of about $47 \mathrm{~mm}$ is embedded on a large slab of shaley greywacke. It is slightly crushed and laterally deformed, so that the dimensions and proportions of the conch can only be estimated. The width

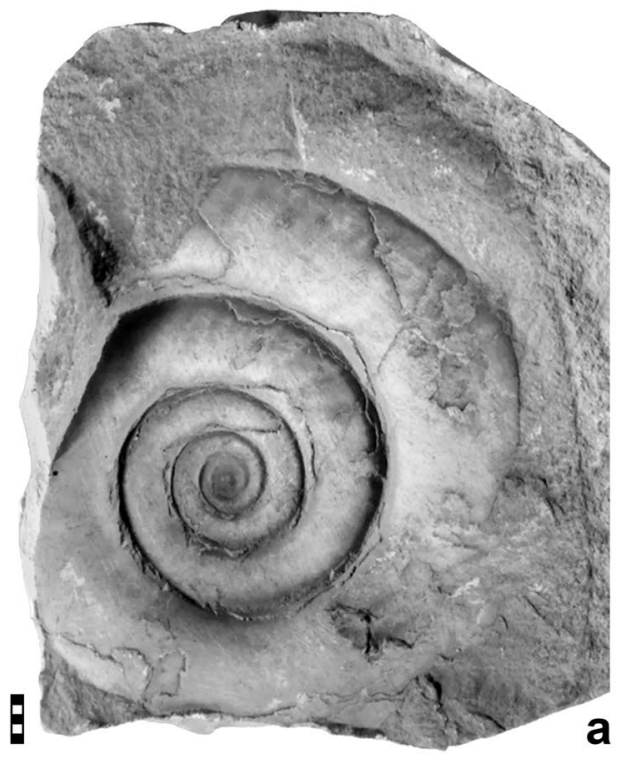

Fig. 2 Ammonoids from the Protocanites Beds of the quarry near the forestry office of Schönau im Wiesental (Schwarzwald). a, b Becanites abnobensis (Vöhringer, 1960), plaster casts of the holotype
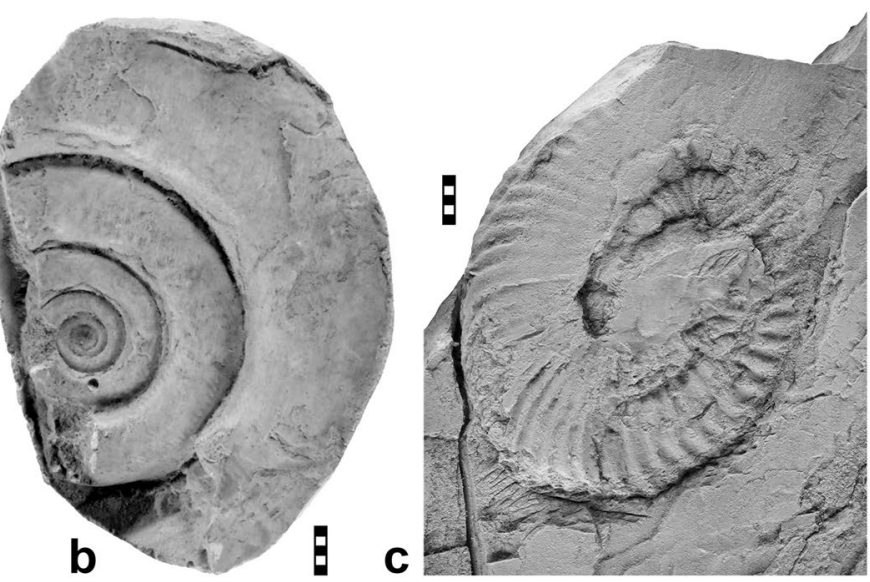

(before and after preparation of the suture line). c Pericyclus princeps (de Koninck, 1844), specimen GZG 190-1. Scale bar units =1 mm 


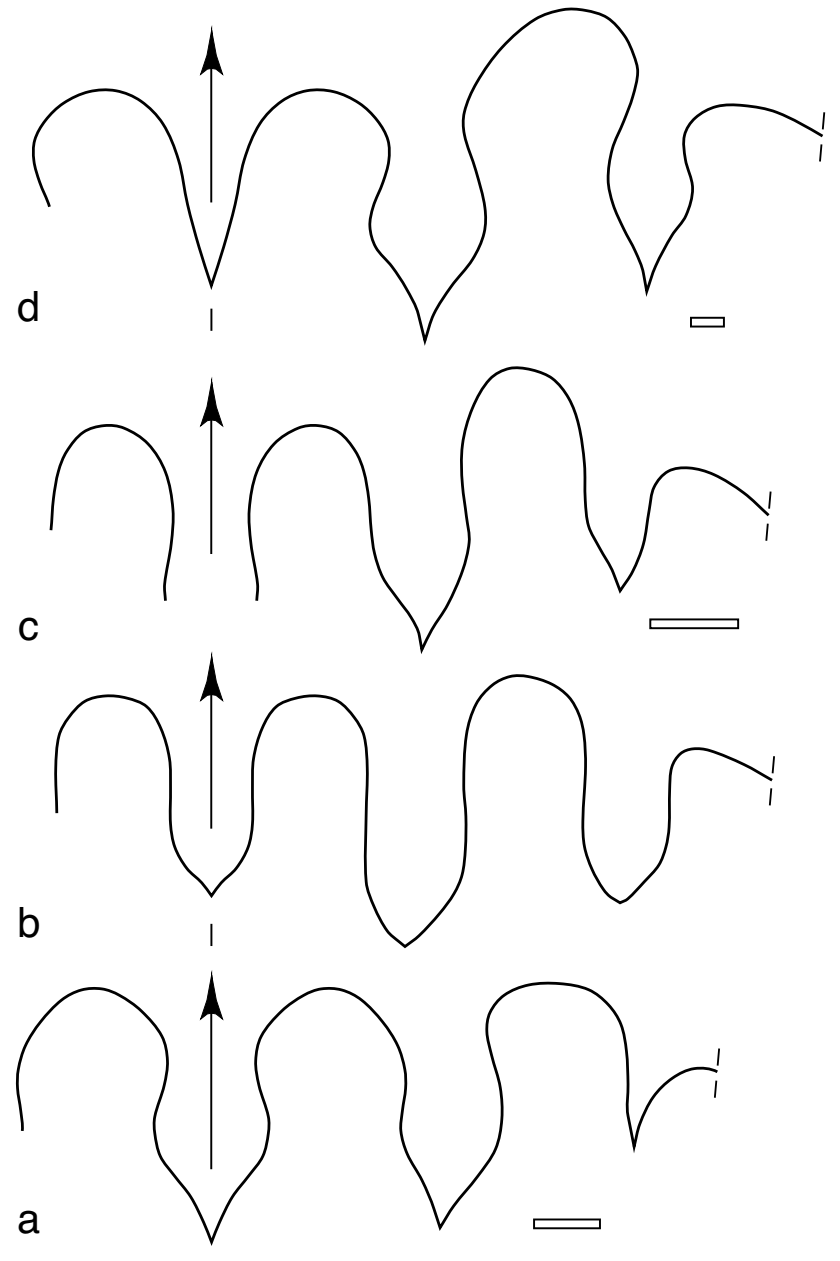

Fig. 3 Suture lines of early representatives of prolecanitid ammonoids. a Eocanites supradevonicus (Schindewolf, 1926) from the Early Tournaisian Hangenberg Limestone of Ober-Rödinghausen (Rhenish Mountains); from Korn (1994). b Becanites abnobensis (Vöhringer, 1960) from the Protocanites Beds of Schönau (Schwarzwald), magnification not stated; from Vöhringer (1960). c Becanites algarbiensis (Pruvost, 1914) from the Bordalete Formation of Bordeira (South Portugal); from Korn (1997). d Protocanites lyoni (Meek and Worthen, 1860) from the Rockford Limestone of Rockford (Indiana); from Miller and Collinson (1951). Scale bar units $=1 \mathrm{~mm}$

of the umbilicus is one-third of the conch diameter. Only one volution can be studied; this bears about 45 rather sharp riblets. They cross the flanks in a slightly anterior direction and turn, in the ventrolateral area, further back to form a deep ventral sinus.

Genus Becanites Korn, 1997

Becanites abnobensis (Vöhringer, 1960)

Figures 2a, b, 3

1910 Prolecanites cf. Lyoni (Meek and Worthen)—Spiegelhalter: 506, text-figs. 1, 2 .
1960 Protocanites supradevonicus abnobensis Vöhringer: 173, text-fig. 52.

Description. Unfortunately, the original specimen could not be traced so far and may have been lost. Only two plaster casts (kept in the geological collection of the Albert-Ludwigs-Universität Freiburg) are available. They are from the same specimen of which Spiegelhalter (1910) had already published a photograph. The casts of the specimen were produced before and after the suture line preparation by Vöhringer (1960).

The specimen had a conch diameter of $60 \mathrm{~mm}$ and was widely umbilicate (umbilicus approximately half of the conch diameter) with almost circular whorl cross-sections. The whorl overlap rate is very low. Smooth shell remains were attached. Since the suture line cannot be studied in the plaster casts, one relies on the figure provided by Vöhringer (1960) (reproduced here in Fig. 3b). In his suture line drawing, a slightly pouched, lanceolate external lobe can be seen, which is shorter than the adventive lobe. This adventive lobe and also the lateral lobe that is located on the flank, closely resemble the external lobe in their lanceolate shape. Only the sizes of the lobes are different, the adventive lobe being the deepest. All the three lobes and the two saddles in between them have the same width.

\section{Conclusions}

The Protocanites Beds of the Badenweiler-Lenzkirch Zone (southern Schwarzwald) are a stratigraphically important key horizon; the formation allows correlation within large areas of the internal zone of the central Variscan Belt of Europe and North Gondwana. However, their age classification has been the subject of controversy over the last 60 years. In order to clarify the stratigraphic position of the Protocanites Beds, we describe two ammonoid specimens that originate from the type locality of the formation in the quarry near the forestry office of Schönau im Wiesental:

(1) Plaster casts of the probably lost holotype of Becanites abnobensis (Vöhringer, 1960), first described as Prolecanites $\mathrm{cf}$. Lyoni by Spiegelhalter (1910), which are permanently kept in the geological collection of the Albert-Ludwigs-Universität Freiburg.

(2) A specimen of Pericyclus princeps (de Koninck, 1844), found in 1961 and first mentioned by Sittig (1967), kept in the collection of the Geowissenschaftliches Museum, Georg-August-Universität Göttingen (GZG). 


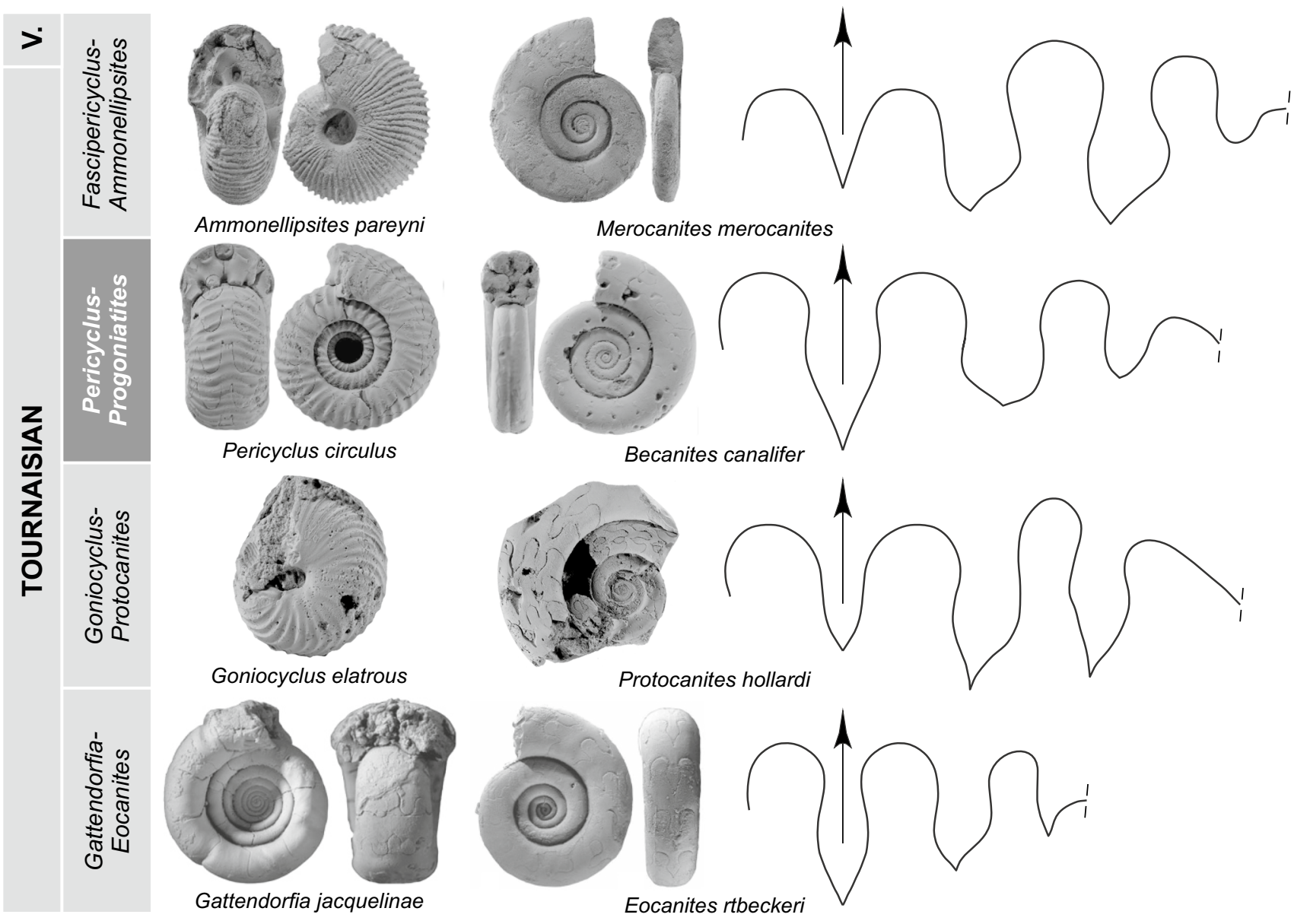

Fig. 4 Tournaisian ammonoid genus zones with representative species occurring in North African occurrences (Bockwinkel and Ebbighausen 2006; Ebbighausen et al. 2010; Korn et al. 2010a, b)

Based on the co-occurrence of these ammonoids, the age of the Protocanites Beds can be precise to a short stratigraphic interval (Pericyclus-Progoniatites genus zone) in the early Late Tournaisian (Fig. 4).

Acknowledgements We are grateful to Ursula Leppig (Freiburg) and Alexander Gehler (Göttingen) for granting us access to the described ammonoids. Thanks to Wolfgang Gerber (Tübingen) and Jenny Huang (Berlin) for photographing the specimens. We benefited from grants of the Deutsche Forschungsgemeinschaft (Ko1829/3-1, Le 690/4-1, Le 690/4-2).

Funding Open Access funding enabled and organized by Projekt DEAL.

Open Access This article is licensed under a Creative Commons Attribution 4.0 International License, which permits use, sharing, adaptation, distribution and reproduction in any medium or format, as long as you give appropriate credit to the original author(s) and the source, provide a link to the Creative Commons licence, and indicate if changes were made. The images or other third party material in this article are included in the article's Creative Commons licence, unless indicated otherwise in a credit line to the material. If material is not included in the article's Creative Commons licence and your intended use is not permitted by statutory regulation or exceeds the permitted use, you will need to obtain permission directly from the copyright holder. To view a copy of this licence, visit http://creativecommons.org/licenses/by/4.0/.

\section{References}

Altherr, R., and R. Maass. 1977. Metamorphite am Südrand der Zentralschwarzwälder Gneissanatexitmasse zwischen Gschwend und Bernau. Neues Jahrbuch für Geologie und Paläontologie, Abhandlungen 154: 129-154.

Becker, R.T., F.M. Gradstein, O. Hammer. 2012. The Devonian period. In The Geologic Time Scale 2012, eds. F. Gradstein, J. Ogg, M. Schmitz, and G. Ogg, 559-601. Elsevier.

Bockwinkel, J., and V. Ebbighausen. 2006. A new ammonoid fauna from the Gattendorfia-Eocanites Genozone of the Anti-Atlas (Early Carboniferous; Morocco). Fossil Record 9: 87-129.

Brockamp, O., A. Schlegel, and K. Wemmer. 2015. Complex hydrothermal alteration and illite $\mathrm{K}-\mathrm{Ar}$ ages in Upper Visean molasse sediments and magmatic rocks of the Variscan Badenweiler-Lenzkirch suture zone, Black Forest, Germany. International Journal of Earth Sciences 104(3): 683-702.

Bubnoff, S. von. 1912. Zur Tektonik des südlichen Schwarzwaldes. Neues Jahrbuch für Mineralogie, Geologie und Paläontologie 1912: 147-156. 
Bubnoff, S. von. 1919. Über den Parallelismus des Untercarbons im Schwarzwald und den Vogesen. Jahresberichte und Mitteilungen des Oberrheinischen Geologischen Vereins 8: 28-36.

Bubnoff, S. von. 1921. Die hercynischen Brüche im Schwarzwald, ihre Beziehung zur carbonischen Faltung und ihre Posthumität. Neues Jahrbuch für Mineralogie, Geologie und Paläontologie, BeilageBand 45: 1-120.

Burgath, K., and R. Maass. 1973. Die variszische Entwicklung im südlichen Schwarzwald. Congrès international de stratigraphie et de géologie du Carbonifère, Comte Rendus, 195-209.

Davydov, V.I., D. Korn, and M.D. Schmitz. 2012. The Carboniferous Period. In The Geologic Time Scale 2012, eds. F. Gradstein, J. Ogg, M. Schmitz, and G. Ogg, 603-651. Elsevier.

Delépine, G. 1940. Les goniatites du Dinantien de la Belgique. Mémoires du Museé Royal d'Histoire Naturelle de Belgique 91: $1-91$.

Ebbighausen, V., D. Korn, and J. Bockwinkel. 2010. The ammonoids from the Dalle à Merocanites of Timimoun (Late TournaisianEarly Visean; Gourara, Algeria). Fossil Record 13: 153-202.

Eisele, J., R. Gertisser, and M. Montenari. 2000. Geochemistry and provenance of Devono-Carboniferous volcano-sedimentary sequences from the Southern Vosges Basin and the geodynamic implications for the western Moldanubian Zone. Geological Society of London, Special Publications 179(1): 433-444.

Franke, W. 1989. Variscan plate tectonics in Central Europe-current ideas and open questions. Tectonophysics 169(4): 221-228.

Franke, W. 2000. The mid-European segment of he Variscides: tectonostratigraphic units, terrane boundaries and plate tectonic evolution. In Orogenic processes: Quantification and Modelling in the Variscan Belt, ed. W. Franke. Geological Society of London, Special Publications 179: 35-61.

Franke, W., R. Dallmeyer, and K. Weber. 1995. Geodynamic evolution. In Pre-Permian geology of central and eastern Europe, eds. R. Dallmeyer, W. Franke, and K. Weber, 579-593. Berlin/Heidelberg/New York: Springer.

Franke, W., V. Haak, O. Oncken, and D. Tanner. 2000. Orogenic processes: quantification and modelling in the Variscan belt. Geological Society of London, Special Publications 179(1): 1-459.

Gruler, M., E. Hegner, F. Chen, and J. Loeschke. 1999. Variskische Suturen-Nd-Isotopie und Zirkonalter für oberdevonisch-unterkarbonische Grauwacken aus dem Moldanubikum des Schwarzwaldes. European Journal of Mineralogy, Beihheft 11: 95.

Güldenpfennig, M. 1997. Geologische Neuaufnahme der Zone von Badenweiler-Lenzkirch (Südschwarzwald) unter besonderer Berücksichtigung unterkarbonischer Vulkanite und Grauwacken. Tübinger Geowissenschaftliche Arbeiten (A) 32: 1-120.

Güldenpfennig, M. 1998. Zur geotektonischen Stellung unterkarbonischer Grauwacken und Vulkanite der Zone von Badenweiler-Lenzkirch (Südschwarzwald). Zeitschrift der Deutschen Geologischen Gesellschaft 149: 213-232.

Güldenpfennig, M., and J. Loeschke. 1991. Petrographie und Geochemie unterkarbonischer Grauwacken und Vulkanite der Zone von Badenweiler-Lenzkirch in der Umgebung von Präg (Südschwarzwald). Jahreshefte des Geologischen Landesamtes in BadenWürttemberg 33: 5-32.

Hann, H.P., and G. Sawatzki. 1998. Deckenbau und Sedimentationsalter im Grundgebirge des Südschwarzwalds/SW-Deutschland. Zeitschrift der Deutschen Geologischen Gesellschaft 149: 183-195.

Hann, H.P., F. Chen, H. Zedler, W. Frisch, and J. Loeschke. 2003. The Rand Granite in the southern Schwarzwald and its geodynamic significance in the Variscan belt of SW Germany. International Journal of Earth Sciences 92(6): 821-842.

Hegner, E., M. Gruler, H. Hann, F. Chen, and M. Güldenpfennig. 2005. Testing tectonic models with geochemical provenance parameters in greywacke. Journal of the Geological Society 162(1): 87-96.
Huth, T., and H. Zedler. 2019. Entlang der kontinentalen Schweißnaht im Südschwarzwald-die Badenweiler-Lenzkirch-Zone (BLZ). Schriftenreihe der Deutschen Gesellschaft für Geowissenschaften 2019: 166-192.

Kalt, A., R. Altherr, and M. Hanel. 2000. Exkursion A: the Variscan Basement of the Schwarzwald. European Journal of Mineralogy, Supplementary Issues 12(2): 1-44.

Kneidl, V., W. Krebs, and R. Maass. 1982. Über Conodontenfunde im Oberdevon von Tunau (Südschwarzwald). Neues Jahrbuch für Geologie und Paläontologie, Monatshefte 1982(1): 25-35.

Koninck, L.-G. de. 1844. Description des animaux fossiles qui se trouvent dans le terrain carbonifère de la Belgique. Bruxelles: $\mathrm{H}$. Dessain.

Koninck, L.-G. de. 1880. Faune du Calcaire Carbonifère de la Belgique, deuxième partie, Genres. Gyroceras, Cyrtoceras, Gomphoceras, Orthoceras, Subclymenia Et Goniatites. Annales du Museé Royal d'Histoire Naturelle, Belgique 5: 1-333.

Korn, D. 1994. Devonische und karbonische Prionoceraten (Cephalopoda, Ammonoidea) aus dem Rheinischen Schiefergebirge. Geologie und Paläontologie in Westfalen 30: 1-85.

Korn, D. 1997. The Palaeozoic ammonoids of the South Portuguese Zone. Memorias do Instituto Geologico e Mineiro 33: 1-131.

Korn, D., J. Bockwinkel, V. Ebbighausen, and C. Klug. 2003. Palaeobiogeographic and evolutionary meaning of an early Late Tournaisian ammonoid fauna from the Tafilalt of Morocco. Acta Palaeontologica Polonica 48: 71-92.

Korn, D., J. Bockwinkel, and V. Ebbighausen. 2007. Tournaisian and Visean ammonoid stratigraphy in North Africa. Neues Jahrbuch für Geologie und Paläontologie, Abhandlungen 243: 127-148.

Korn, D., J. Bockwinkel, and V. Ebbighausen. 2010a. The ammonoids from the Argiles de Teguentour of Oued Temertasset (early Late Tournaisian; Mouydir, Algeria). Fossil Record 13: 35-152.

Korn, D., V. Ebbighausen, and J. Bockwinkel. 2010b. The ammonoids from the Gres du Kahla superieur of Timimoun (Middle-early Late Tournaisian; Gourara, Algeria). Fossil Record 13: 13-34.

Korn, D., and C. Klug. 2015. Paleozoic Ammonoid Biostratigraphy. In Ammonoid Paleobiology: From macroevolution to paleogeography, eds. C. Klug, D. Korn, K. De Baets, I. Kruta, and R.H. Mapes. Topics in Geobiology. https://doi.org/10.1007/978-94017-9633-0_12.

Kossmat, F. 1927. Gliederung des varistischen Gebirgsbaues. Abhandlungen des Sächsischen Geologischen Landesamtes 1: 1-37.

Leloix, C., M. Faure, and J.-L. Feybesse. 1999. Hercynian polyphase tectonics in the northeast French Massif Central: the closure of the Brévenne Devonian-Dinantian rift. International Journal of Earth Sciences 88(3): 409-421.

Loeschke, J., M. Güldenpfennig, H.P. Hann, and G. Sawatzki. 1998. Die Zone von Badenweiler-Lenzkirch (Schwarzwald): Eine variskische Suturzone. Zeitschrift der Deutschen Geologischen Gesellschaft 149: 197-212.

Maass, R. 1988. Die Südvogesen in variszischer Zeit. Neues Jahrbuch für Geologie und Paläontologie, Monatshefte 1988(10): 611-638.

Maass, R. 2005. Die Variszischen Massive am Oberrhein, Bindeglied zwischen Mitteldeutschland und dem Zentralmassiv. Zeitschrift der Deutschen Gesellschaft für Geowissenschaften 156(4): 589-614

Maass, R. 2006. Die Oberrheinischen Massive. Schriftenreihe der Deutschen Gesellschaft für Geowissenschaften 41: 558-580.

Maass, R., T. Prosch, and D. Schuler. 1991. The zone of Badenweiler-Lenzkirch-a Carboniferous accretionary wedge? Neues Jahrbuch für Geologie und Paläontologie, Monatshefte 1990(12): 717-734. 
Matte, P. 1991. Accretionary history and crustal evolution of the Variscan belt in Western Europe. Tectonophysics 196(3-4): 309-337.

Meek, F.B., and A.H. Worthen. 1860. Descriptions of new Carboniferous fossils from Illinois and other western states. Proceedings of the Academy of Natural Sciences Philadelphia 1860: 447-472.

Metz, R., and G. Rein. 1958. Erläuterungen zur geologisch-petrographischen Übersichtskarte des Südschwarzwaldes. Laar: Schauenburg.

Miller, A.K., and C. Collinson. 1951. Lower Mississippian ammonoids of Missouri. Journal of Paleontology 25: 454-487.

Mojsisovics, E. von. 1882. Die Cephalopoden der mediterranen Triasprovinz. Abhandlungen der Kaiserlichen und Königlichen Geologischen Reichsanstalt 10: 1-322.

Montenari, M., and T. Servais. 2000. Early Paleozoic (Late CambrianEarly Ordovician) acritarchs from the metasedimentary BadenBaden-Gaggenau zone (Schwarzwald, SW Germany). Review of Palaeobotany and Palynology 113(1-3): 73-85.

Montenari, M., T. Servais, and F. Paris. 2000. Palynological dating (acritarchs and chitinozoans) of Lower Paleozoic phyllites from the Black Forest/southwestern Germany. Comptes Rendus de l'Académie des Sciences (IIA: Earth and Planetary Science) 330 (7): 493-499.

Pruvost, P. 1914. Observations sur les terrains Dévoniens et Carbonifères du Portugal et leur faune. Comunicaçoes da Comissao do Serviço Geológico de Portugal 10: 1-22.

Schäfer, M. 1957. Die devonischen Sedimente der Südschwarzwälder Hauptbewegungszone. Mitteilungen und Arbeiten des GeologischPaläontologischen Institutes der Technischen Hochschule Stuttgart (Neue Folge) 7: 1-87.

Schaltegger, U. 2000. U-Pb geochronology of the Southern Black Forest Batholith (Central Variscan Belt): timing of exhumation and granite emplacement. International Journal of Earth Sciences 88 (4): 814-828.

Schindewolf, O. H. 1926. Zur Kenntnis der Devon-Karbon-Grenze in Deutschland. Zeitschrift der Deutschen Geologischen Gesellschaft 78: 88-133.

Sittig, E. 1961. Ein mariner Horizont des Visé (Oberes Unterkarbon) im Südschwarzwald und seine Fauna. Jahreshefte des Geologischen Landesamtes Baden-Württemberg 5: 195-242.

Sittig, E. 1963. Synsedimentäre Rutschungen im Unterkarbon des Südschwarzwaldes. Oberrheinische Geologische Abhandlungen 12: 81-94.

Sittig, E. 1965. Der geologische Bau des variszischen Sockels nordoestlich von Baden-Baden (Nordschwarzwald). Oberrheinische Geologische Abhandlungen 14(1-2): 167-207.
Sittig, E. 1967. Zur Fazies und Verbreitung des marinen Viseum (Oberes Unterkarbon) im Südschwarzwald. Oberrheinische Geologische Abhandlungen 16: 37-43.

Sittig, E. 1969. Zur geologischen Charakterisierung des Moldanubikums am Oberrhein Schwarzwald. Oberrheinische Geologische Abhandlungen 18: 119-161.

Sittig, E. 1981. Evidence for wrench faulting within the Paleozoic Badenweiler-Lenzkirch zone (Southern Schwarzwald Mountains, W-Germany). Neues Jahrbuch für Geologie und Paläontologie, Monatshefte 1981(7): 431-448.

Spiegelhalter, F. 1910. Ein Goniatit aus dem südlichen Schwarzwald. Centralblatt für Mineralogie, Geologie und Palaeontologie 1910: 506-510.

Vaida, M., H. Hann, G. Sawatzki, and W. Frisch. 2004. Ordovician and Silurian protolith ages of metamorphosed clastic sedimentary rocks from the southern Schwarzwald, SW Germany: a palynological study and its bearing on the Early Palaeozoic geotectonic evolution. Geological Magazine 141(5): 629-643.

Vöhringer, E. 1960. Die Goniatiten der unterkarbonischen Gattendorfia-Stufe im Hönnetal (Sauerland). Fortschritte in der Geologie von Rheinland und Westfalen 3: 107-196.

Werling, E., and R. Altherr. 1987. The southern border of the gneiss mass of the central Black Forest: an inverse metamorphic profile interpreted as Variscan backthrust. Terra Cognita 7(2): 173.

Weyer, D. 1962. Zwei Oberdevon-Faunen von Schönau im Südschwarzwald. Geologie 11: 384-396.

Wickert, F., R. Altherr, and M. Deutsch. 1990. Polyphase Variscan tectonics and metamorphism along a segment of the Saxothuringian-Moldanubian boundary: the Baden-Baden Zone, northern Schwarzwald (FRG). Geologische Rundschau 79(3): 627-647.

Wilser, J.L. 1933. Das Unterkarbon von Badenweiler-Schweighof im südlichen Schwarzwald. Centralblatt für Mineralogie etc. 10: 446-457.

Wimmenauer, W. 1984. Das prävariskische Kristallin im Schwarzwald. Fortschritte der Mineralogie, Beiheft 62(2): 69-86.

Wimmenauer, W., H. Prier, A. Schreiner, and K. Stahr. 1981. Erläuterungen zu Blatt 8114 Feldberg. Geologische Karte 1:25.000 von Baden-Württemberg.

Ziegler, P.A., and W. Wimmenauer. 2001. Possible glaciomarine diamictites in lower Paleozoic series of the southern black forest (Germany): implications for the Gondwana/Laurussia puzzle. Neues Jahrbuch für Geologie und Paläontologie, Monatshefte 2001(8): 500-512. 